\section{Kvasnikov V., Perederko A.}

\title{
DEVELOPMENT OF METHODS OF PROCESSING SENSOR SIGNAL
}

Об’єктом дослідження є процес обробки сигналу первинного перетворювача певним методом. При проведенні вимірювань на первинний перетворювач вимірювальної системи, окрім дії параметру вимірювань, діє безліч вторинних впливів. Одним з них є зміна температури середовища. Це приводить до появи в вимірюваному сигналі такої компоненти, як додатковий постійний рівень. Він обумовлений генерацією первинним перетворювачем при відсутності впливу з боку об'єкта вимірювань додаткового заряду, потениіалу. Тобто, при відсутності дї зі сторони параметру вимірювань спостерігається зрушення нульового рівня сигналу первинного перетворювача. Таким чином коливання температури середовища приводять до появи неінформативної складової в сигналі вимірювань. Тобто, отримуємо збільшення похибки результату вимірювання. Принцип методу, яким оброблявся у роботі сигнал первинного перетворювача, викладений на прикладі вимірювання вібрацї n'єзоелектричним акселерометром. Запропонований метод обробки сигналу вимірювання дозволяє виокремити постійну складову з комплексного сигналу вимірювання. Це досягається шляхом подачі вимірювального сигналу по двом паралельним каналам, в одному з яких сигнал затримується по фазі на половину періоду відносно другого з подальшою обробкою на суматорі. Так як сигнал з первинного перетворювача має широку частотну смугу, то необхідно забезпечити точність затримки по фазі. Це досягається шляхом переналаштування ланки постійної часу фазових фільтрів. Переналаштування здійснюється за допомогою перетворювача частота-напруга, який відстежує частоту вимірюваного сигналу. Оскільки зміни температури в часі, в порівнянні з частотою вимірюваних вібрацій, значно повільніші, то неточність роботи схеми практично відсутня. Тобто неточність визначення постійної складової в комплексному сигналі буде визначатися різницею амплітуд суміжних напівперіодів. Отримані результати дозволяють стверджувати, що даний метод можливо використовувати як для корекцї самого первинного перетворювача (шляхом впливу на його передатну функцію), так $і$ для корекцї результатів вимірювань взагалі.

Ключові слова: первинний перетворювач, обкладки n'єзоелемента, п'єзоелектричний акселерометр, фазовий фільтр першого порядку, фазовий зсув.

\section{Introduction}

Modern technology development to ensure reliable monitoring and control in technical systems requires the presence of high-precision measuring tools. They allow to measure the technological parameters during operation and optimize the processes of creating new samples at the design and testing stage. In a wide range of mechanical quantities measured in technical systems, a special place is occupied by measurements of parameters such as acceleration, speed, displacement, vibrations. In measurements, direct or indirect, the primary element of the measuring system is the primary transducer (sensor). It is an analog device or device built on the basis of the realization of certain physical properties and is capable of transforming the influence that the medium has on it or the object of measurement into a form acceptable for display, processing and recording. In the process of measuring, in production conditions, the primary transducers, in addition to the parameter being measured, are affected by many destabilizing factors, such as extraneous vibrations, rapid changes in ambient temperature, electrical interference and electromagnetic fields [1]. In the complex, these factors affect the normal operation of sensors: the accuracy and reliability of measurements decreases. To prevent these effects, it is necessary to apply additional circuit or al- gorithmic solutions when processing the measurement signal. In the works of many authors, the question of zero drift of piezoelectric under the influence of temperature was raised [2-4]. The presence of this phenomenon was confirmed by the author of the work [5], where the dependence of the piezoelectric modules on temperature was experimentally proved. This opinion was also shared by the authors of studies [6-8], who offered their technical solutions for leveling this effect on the measurement results. So, the direction of research outlined in this work is relevant today.

Thus, the object of research is the processing of the signal of the primary converter by a certain method. And the aim of research is reducing the influence of temperature fluctuations on the reliability of measurement results.

\section{Methods of research}

When conducting research was used:

- theory of signal processing and the theory of measurements, which were used to analyze and reduce errors;

- theory of the study of vibration and shock signals, based on the use of spectral and statistical analysis of time series as applied to the signals of piezoelectric acceleration sensors. 


\section{Research results and discussion}

Many analog primary converters have such a phenomenon as zero drift - fluctuation of the level of the constant component in the complex useful signal in the measurement process. These fluctuations are caused by factors influencing the environment on the measurement conditions and the actual physical properties of the most primary transducers. They do not carry any informative component and introduce an error in the measurement. For example, an external environment factor, such as temperature, the value of which changes rapidly over time over a wide range, when measuring, acts on the piezoelectric element operating on the primary isolate as a sensor of the piezoelectric accelerometer. These changes in temperature lead to the appearance of additional charges on the plates of the piezoelement:

$$
q=d_{33} \cdot F
$$

where $q$ - the charge on the electrodes of the piezoelectric element; $d_{33}$ - piezomodule (longitudinal axis of residual polarization Z); $F$ - external force acting on the accelerometer.

Fig. 1 shows the temperature dependence of the piezoelectric module $d_{33}$ on temperature [5] in the temperature range from $20{ }^{\circ} \mathrm{C}$ to $250{ }^{\circ} \mathrm{C}$ (the upper range is half the Curie temperature for the studied ceramic material) for the ЦТС-19б piezoceramics (JSC Elpa, Russia).

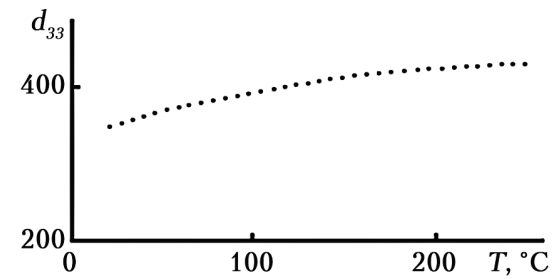

Fig. 1. Temperature dependence of piezoelectric module $d_{33}$ of piezoelectric ceramics PZT-19b

From the graph in Fig. 1 it is possible to see that the piezoelectric module $d_{33}$ longitudinal along the axis of residual polarization depends on temperature $[9,10]$ and this dependence is nonlinear.

In this paper, method for isolating the constant component of a complex signal is considered, which consists in the fact that a complex signal is delayed by a parallel channel in phase for half a period, and then added to the signal of the main channel on the adder. Thus, the variable components of the complex signal in the entire dynamic range of the frequency signal arrive at the adder in antiphase, and are mutually subtracted. The block diagram of the implementation of this method is shown in Fig. 2.

In the parallel channel for the delay of the signals applied phase filters of the first order. The condition for error-free signal transmission is a constant transmission coefficient. In phase filters, this condition is completely satisfied. The second condition is that the group delay of the filter for the entire dynamic frequency range of the primary converter is constant.

The first order phase filter in Fig. 3 can be used as a broadband delayer of phases. The transfer function of the filter of the first order according to Fig. 3 has the form:

$$
K(p)=\frac{1-p R 2 C}{1+p R 2 C}
$$

where $R 2, C$ - the components of the first order phase filter.

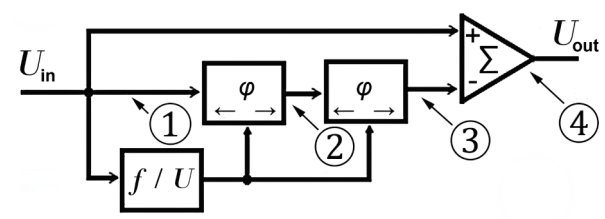

Fig. 2. Block diagram of the selection of the constant component of the complex signal of the primary converter. $U_{i n}$ - input complex measurement signal; $U_{\text {out }}$ - dedicated constant component of the complex signal of measurement; $\varphi$ - phase filter; $\Sigma$-adder; 1, 2, 3, 4 - waveform measurement points; $f / U$ - frequency-voltage converter

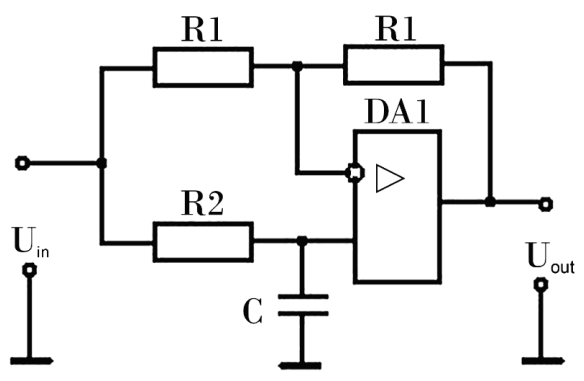

Fig. 3. First order phase filter.

B1, $B 2$ - resistance; $C$ - capacitance, $D A 1$ - operational amplifier

A feature of the first order phase filter is that by changing the resistance value of the resistor $R 2$, it is possible to set the phase shift in the range from 0 to $-180^{\circ}$ without changing the amplitude of the output signal. The magnitude of the phase shift angle $\alpha$ in degrees for the phase filter circuit in Fig. 4 is calculated by the formula:

$$
\alpha=\frac{-2 \operatorname{arctg}(\omega R 2 C) 180^{\circ}}{\pi},
$$

where $\omega=2 \pi f$.

To ensure the regulation of phase delay in a wide range, two series-connected phase detectors are used, the ratings of which are set to a signal phase delay $-90^{\circ}$ each.

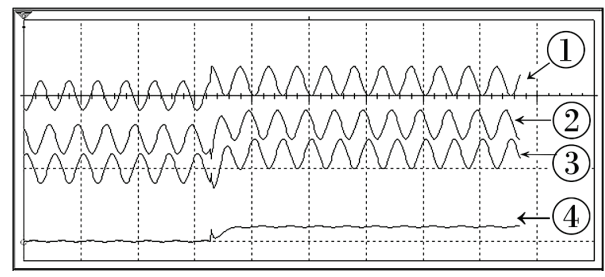

Fig. 4. Oscillograms of the operation of the allocation of the constant component of the integrated signal of the primary converter. The oscillograms 1, 2, 3, 4 correspond to the measurement points of the oscillograms on the block diagram of Fig. 2

As a result, the two phase filters in the total delay the signal by $180^{\circ}$, and on the adder with a transfer coefficient of 0.5 (Fig. 2), the signals are added together. As a result, at the output let's get a constant component with a transfer coefficient equal to one. The operation of the constant component isolation circuit according to 
the complex signal of the primary converter is shown in oscillograms in Fig. 4.

From the formula (3) it is possible to that the phase delay also depends on the frequency of the signal entering the input of the phase filter. Therefore, to ensure stable compensation of the constant component of the signal in the entire dynamic range of the primary converter, and these are frequency ranges, generally from $3-10 \mathrm{~Hz}$ to $10-15 \mathrm{kHz}$, it is necessary to change the time constant of the delayed phase filter circuit. This circuit is implemented on the elements $R 2$ and $C$ (scheme in Fig. 4). It is technically more convenient to change the time constant by changing the resistance of the resistor $R$ at $C=$ const. The operation of the constant component isolation circuit according to the complex signal of the primary converter is shown in oscillograms in Fig. 4.

The dependence of the resistance value $R 2$ of the phase filter on the frequency of the signal $f$ in the dynamic range of $10 \ldots 10000 \mathrm{~Hz}$ to ensure a delay of $90^{\circ}$ throughout the entire range is shown in Fig. 5.

To ensure the regulation of the resistance value $R$ within the specified range, the frequency-voltage converter $f / U$ is used in the phase filter circuit (Fig. 2). Thus, as the frequency of the signal increases, the voltage $U$ at the output of the frequency-voltage converter increases. This causes a proportional decrease in the resistance of the electronic switch connected in parallel to the resistor $R 2$ and, as a result, reduces the time constant of the phase filter circuit.

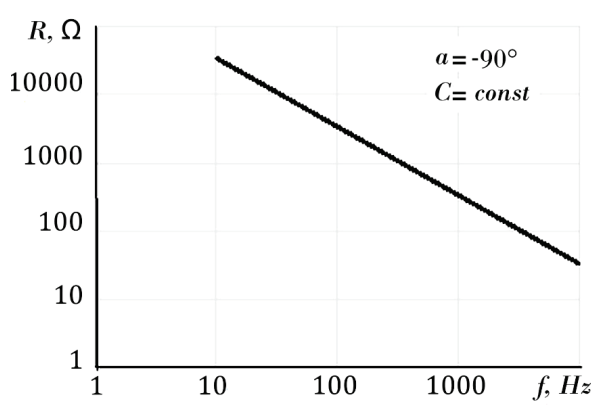

Fig. 5. Dependence of $R 2$ value on frequency $f$

As can be seen from Fig. 5, the dependence of $R 2$ on frequency $f$ is linear over the entire defined range. That is, the construction of the control circuit of the time constant of the $R 2 C$ circuit (Fig. 4) by the signal from the frequency-voltage converter $f / U$ (Fig. 2) from the point of view of the technical implementation has no complications.

\section{Conclusions}

The selected constant component of the complex signal can be classified as an additive measurement error caused by an external temperature effect. In the future, this constant component can be used for the correction of both the primary converter itself and for the correction of measurement results in general. Correction of the primary converter is possible by affecting its transfer function.

Since the information content of the primary converter is characterized by dynamic and frequency ranges, the proposed method of correction of the constant component is promising. It allows to improve the measurement accuracy and expand the scope of the primary transducers regarding the requirements for the ambient temperature and other influences that lead to changes in the constant component without affecting the information parameter during measurements.

\section{References}

1. Datchiki / Sharapov V. M., Polishchuk E. S., Koshevoi N. D. et. al.; ed. by Sharapov V. M., Polishchuk E. S. Moscow, 2012. 624 p.

2. Proektirovanie datchikov dlia izmereniia mekhanicheskikh velichin / Osadchii E. P. Tikhonov A. I., Karpov V. I., Zhuchkov A. I., Volkov V. A., Novickii P. V. et. al.; ed. by Osadchego E. P. Moscow, 1979. 480 p.

3. Second IFAC Workshop on Adaptive Systems in Control and Signal Processing 1986 // Adaptive Systems in Control and Signal Processing 1986. Elsevier, 1987. 454 p. doi: http://doi.org/ 10.1016/b978-0-08-034085-2.50004-3

4. Dorf R. C., Bishop R. H. Modern Control Systems. Pearson, 2016. 1032 p.

5. Antonenko A. M., Kudzin A. Iu., Gavshin M. G. Vliianie domennoi struktury na elektromekhanicheskie svoistva segnetokeramiki CTS i MNVT // Fizika tverdogo tela. 1997. Vol. 39, Issue 5. P. 920-921.

6. Pezoelektricheskii datchik udara: pat. RU 2533539. MPK G01P 15/09, H01L41/083 / Kaplunov I. A., Malyshkina O. V., Golovnin V. A., Inozemcev N. V., Dolnikov G. G. declareted: 27.05.2013; published: 20.11.2014. 9 p.

7. Kleckers T. Force sensors for strain gauge and piezoelectric crystal-based mechatronic systems- a comparison // 2012 IEEE International Instrumentation and Measurement Technology Conference Proceedings. IEEE, 2012. doi: http://doi.org/ 10.1109/i2mtc. 2012.6229515

8. Mekhanicheskii filtr dlia pezoakselerometra: pat. RU 2410704 . MPK G01P 15/09; declareted: 02.02.2009; published: 27.01.2011. $12 \mathrm{p}$.

9. Pezoelektricheskoe priborostroenie / Gorish A. V., Dudkevich V. P., Kupriianov M. F.; ed. by Gorish A. V. Moscow, 1999. 367 p.

10. Ageikin D. I., Kostina E. N., Kuznecov N. N. Datchiki kontrolia i regulirovaniia. Moscow, 1965. 914 p.

Kvasnikov Volodymyr, Doctor of Technical Sciences, Honored Metrologist of Ukraine, Head of Department of Computerized Electrical Systems and Technologies, National Aviation University, Kyiv, Ukraine, e-mail: kvp@nau.edu.ua, ORCID: http://orcid.org/00000002-7799-0001

Perederko Anatolij, PhD, Department of Metrology and Metrological Support, Odessa State Academy of Technical Regulation and Quality,Ukraine, e-mail: pal88@ukr.net, ORCID: http://orcid.org/ 0000-0002-9625-4798 